Accepted for publication in Journal of Orthodox Christian Studies, John Hopkins University

Press

\title{
The Ukrainian National Church, Religious Diplomacy and the Conflict in Donbas
}

\author{
Lucian N. Leustean and Vsevolod Samokhvalov
}

\begin{abstract}
Authors
Lucian N. Leustean, Aston University, Birmingham, United Kingdom

1.1eustean@aston.ac.uk

ORCID number: https://orcid.org/0000-0002-1137-2307

Vsevolod Samokhvalov, Vesalius College, Brussels, Belgium samokhvalovvsevolod@googlemail.com

ORCID number: https://orcid.org/0000-0002-5667-8668
\end{abstract}

\begin{abstract}
(150 words)
The article analyses political mobilisation towards the establishment of an independent Ukrainian national church. Ukraine had three Orthodox churches, the largest of which is under the jurisdiction of the Moscow Patriarchate, while the others lacked ecclesiastical legitimacy. On 11 October 2018, in a dramatic decision with geopolitical consequences, the Kyiv Patriarchate received ecclesiastical recognition from the Istanbul-based Ecumenical Patriarchate. Drawing on 16 interviews with key clergy, academics and policy practitioners working on church-state relations in Kyiv, a literature review, and online data from Bulgarian, Greek, Polish, Romanian, Russian, Serbian and Ukrainian sources, the article argues that the conflict in Donbas has been a key factor in the national and international mobilisation towards autocephaly. This article demonstrates that in Eastern Orthodoxy, churches perform state-like functions in three areas, namely establishing diplomatic channels of communication; mobilising the faithful at national and international levels; and advancing human security discourses on violence, survival and tolerance.
\end{abstract}

\section{Keywords}

Ukraine; religion and politics; Eastern Orthodox Christianity; religious diplomacy; violence

\section{Acknowledgements}

Qualitative data collection in Kyiv has been supported by 1) the British Academy Grant 'British Academy Grant IC2 $\backslash 100047$ 'Forced Migration, Religious Diplomacy and Human Security in the Eastern Orthodox World' awarded under The Humanities and Social Sciences Tackling the UK's International Challenges Programme; 1 January-31 December 2018 (Lucian N. Leustean, Principal Investigator) and 2) a Marie Currie Fellowship BeIPD-COFUND at the University of Liege, Belgium (Vsevolod Samokhvalov). Two anonymous reviewers and the journal editors, George Demacopoulos and Vera Shevzov, have been extremely helpful in offering detailed and insightful comments on an earlier draft. Lucian N. Leustean is also grateful to the staff members of the Netherlands Institute for Advanced Studies in the 
Humanities and Social Sciences, Amsterdam for their feedback and support during his fellowship in residence where he finalised this article.

\section{Introduction}

On 21 November 2016, in a ceremony at the Cathedral of Christ the Saviour in Moscow celebrating his $70^{\text {th }}$ anniversary, Patriarch Kirill stated that 'Our church will never leave Ukrainian brothers in trouble and will not abandon them. We will never agree to change the sacred canonical borders of the Church, because Kyiv is the spiritual cradle of holy Rus', like Mtskheta for Georgia and Kosovo or for Serbia'. ${ }^{1}$ These passionate remarks, which led to applause from the audience and were witnessed by heads and representatives from fifteen churches, including Metropolitan Onufriy, Head of the Ukrainian Orthodox Church - Moscow Patriarchate, summarise one of the most contentious issues in contemporary Eastern Orthodox Christianity, namely the debates on Ukrainian autocephaly (independence) and Russia's ecclesiastical links with the Orthodox faithful in Ukraine. Why do Orthodox churches need autocephaly? Eastern Orthodoxy, the third largest branch of Christianity, brings together around 300 million faithful divided along national lines (Angold, 2006; Demacopoulos and Papanikolaou, 2013; Leustean, 2014; Prodromou, 2004; Ramet, 1988; Roudometof, 2013). Institutionally, fourteen Orthodox churches are in communion with each other acknowledging the primus inter pares role of the Istanbul-based Ecumenical Patriarchate of Constantinople. ${ }^{2}$ As a general rule, Orthodox churches acquired autocephaly as part of their nation-building processes. Both church and state leaders appealed to the Ecumenical Patriarchate, the only church widely regarded by most hierarchs and theologians with the authority to enable new Churches to become an integral part of the Orthodox commonwealth.

The Ecumenical Patriarchate's authority to bestow autocephaly has been disputed and regularly challenged by the Russian Orthodox Church (ROC). The Ecumenical Patriarchate dates back to the Christian Church established by Emperor Constantine (306-337) who moved the capital of the Roman Empire to Constantinople in 323. After the 1453 fall of Byzantium, the Patriarchate remained the centre of ecclesiastical and political power for the Christian faithful in the Ottoman Empire. Today, the Patriarchate looks after a small number of faithful in Turkey while a significant number of communities are under its jurisdiction in Western Europe, the United States and Canada. In contrast to national Orthodox churches, the Patriarchate is not linked to nation-building processes. Discrepancies in the number of faithful and state support characterise relations between the Ecumenical Patriarchate and the Russian Orthodox Church. The Moscow Patriarchate brings together not only the largest number of Orthodox faithful in the world but also exerts considerable geopolitical influence outside the country's borders.

Among Orthodox churches, the Ukrainian case stands out. First, the Orthodox faithful have been divided among three churches, the largest of which is under the jurisdiction of the Russian Orthodox Church while large segments of Ukrainian diaspora, particularly in Canada, are under that of the Ecumenical Patriarchate. Second, Russia's annexation of Crimea and the conflict in the Donbas region have led to unprecedented religious and political mobilisation towards obtaining autocephaly. The independence of the Ukrainian Church has been regularly presented by politicians as directly linked to state independence. Third, a unified and ecclesiastically recognised Ukrainian Church would represent not only a diminishing of Russia's authority in Ukraine, but most importantly would lead to the formation of the second largest Orthodox Church in the world. Russia would continue to hold the largest number of Orthodox faithful with around 110 million, followed by Ukraine with 40 million and Romania with 18 million (Pew Research Centre, 2017). Hierarchs from other Orthodox churches have been asked to support either the Ecumenical Patriarchate or the Russian position 
communicating directly with Ukrainian political authorities. For example, on 12 June 2017, the Bulgarian Orthodox Church sent a letter to President Poroshenko supporting the UOC-MP thus going beyond standard protocol which requires that diplomatic messages are transmitted through state bodies rather than religious channels. ${ }^{3}$

The diplomacy adopted by Orthodox churches increased after the December 2013January 2014 Maidan Revolution, the post-March 2014 takeover of Crimea and the conflict in Donbas (Bertelsen, 2016; Denysenko, 2014; Dragneva and Wolczuk, 2015; Elliott, 2014; Fylypovych and Horkusha, 2015; Kozelsky, 2014; Krawchuk and Bremer, 2016; Mitrokhin, 2010; Mearsheimer, 2014; Petro, 2017; Samokhvalov, 2015 and 2017; Simons, 2015; van der Laarse et al, 2015; Wilson, 2000 and 2014). While the exact figures remain disputed, international organisations estimate that over 10,000 people died in Donbas, 2,800 of which were civilians. Despite the Minsk Protocols which stopped belligerent forces, clashes, injuries and deaths occur every week in the buffer zone between Ukrainian military forces and proseparatists troops (Interviews 1, 2, 3, 4, 6 and 14). The Donbas conflict has been described as 'among the worst humanitarian crises in the world' while 'one-third of all Donbas medical facilities have been damaged' affecting 6.6 million people living in the region, around $15 \%$ of Ukraine's total population. ${ }^{4}$ The United Nations Refugee Agency has reported that Ukraine is the ninth largest country in the world with over 1.5 million internally displaced people (Crimean Human Rights Group, 2018; Mavelli and Wilson, 2017; Wood et al, 2016; Yekelchyk, 2015). ${ }^{5}$

This article focuses on the ways in which religious and state diplomacy worked together towards the granting of Ukrainian autocephaly.. Drawing on 16 interviews with key academics, clergy and policy practitioners working on church-state relations in Kyiv conducted between March and October 2018, a literature review, and online data from Bulgarian, Greek, Polish, Romanian, Russian, Serbian and Ukrainian sources, it examines the political mobilisation of Orthodox churches towards the establishment of an independent Ukrainian national church. The nterviews were conducted with lower clergy (priests/deans), top clergy (bishops/metropolitans) and employees working in church bodies. As we interviewed church leaders from both UOC-KP and UOC-MP data from interviews has been collated to ensure participants' anonymity. Each interview with church leaders lasted around one hour and followed a semi-structured approach.

We argue that the conflict in Donbas has been a key factor in the national and international mobilisation towards autocephaly. While autocephaly was officially proclaimed by the Ecumenical Patriarchate on 6 January 2019, we demonstrate that the decision taken on 11 October 2018 was the result of the ways in which churches engaged with violence in Donbas leading to a direct split among key churches in the Orthodox commonwealth. The article focuses on events leading to the 11 October decision and shows that in Eastern Orthodox Christianity, Orthodox churches project state-like functions in three key areas, namely establishing diplomatic channels of communication; mobilising the faithful at both national and international levels; and advancing human security discourses on violence, survival and tolerance.

\section{The Ukrainian Orthodoxy: Pro-Independence and Pro-Moscow Wings}

During the Soviet period, religious communities were harshly persecuted by the atheist state with the Greek Catholic Church, predominantly based in the western part of the country, abolished (Bociurkiw, 1996; Himka, 1999). When Ukraine gained state independence status in 1991, religious and political elites not only recognised the Greek Catholic Church but also raised the question of the opportunity to establish an independent Ukrainian Church (Bociurkiw, 1990; Kazmina and Filippova, 2005; Plokhy and Sysyn, 2003). The proposal to 
do so was put forward due to three factors. First, autocephaly has been linked to independent statehood as most predominantly Orthodox countries have their own national Church. Second, the Ukrainian Orthodox Church had historical grounds to claim independence. The Ukrainian lands, and Kyiv in particular, had been the centre of Slavonic Orthodoxy. The Medieval principality of the Kyivan Rus' was the place where the Slavic tribes converted to the Eastern Orthodox Christianity of the Byzantine Empire. From the tenth until the seventeenth century, the Orthodox Church in Ukrainian territory had the status of a metropolis of the Ecumenical Patriarchate. The jurisdiction changed in 1686 when the Russian Empire exerted pressure on the Ecumenical Patriarchate and took control of the Kyiv metropolis. Third, as part of the Soviet Union, Kyiv was presented as the 'cradle of the three fraternal Eastern Slavic nations', namely the Russian, Ukrainian and Belarusian nations. Ukraine was one of the most populous Soviet republics with a high degree of religiosity, bringing together nearly half of the parishes for the whole Russian Orthodox Church. Despite religious persecution, Ukraine hosted a significant number of monastic communities, including the most famous and earliest monastic complex and pilgrimage destination, Pechersk Lavra, as well as educational establishments in Kyiv and Odessa, the latter one of the few centres allowed to operate under the Soviet atheist policy. Part of the challenge in assessing religious jurisdiction in Ukraine has been due to the fact that there has been no single agreed map that defines 'Ukrainian territory'. Ukraine's borders have constantly shifted throughout history (Fagan, 2013; Plokhy, 2015; Senyk, 1993 and 2011; Wanner, 2012).

When the Soviet Union collapsed, three key elements stood out in the secessionist drive of Ukrainian congregations from the jurisdiction of the Russian Orthodox Church, namely historical narrative, church size and institutional infrastructure. The most visible supporter of an independent Ukrainian Church was the local primate of the Russian Orthodox Church in Ukraine, Metropolitan Filaret (Denysenko). Metropolitan Filaret, who served for decades in the Russian Orthodox Church, started informal negotiations with Moscow on obtaining autonomy status for his Church in Ukraine. At first, Filaret seemed to appeal to both sides, by rejecting calls for independence. On 9 May 1989, when asked about his view of the emergence of the newly-formed Ukrainian Autocephalous Orthodox Church (UAOC), he stated that 'And our Church, as is known from history, does everything for the union of peoples. Therefore, it is against autocephaly' (Sysyn, 2003: 94). On 25-27 October 1990, Moscow granted the Ukrainian Orthodox Church self-governing rights (which implied a unique status as part of the Russian Orthodox Church, not 'autonomy' or 'autocephaly'); however, a few months later, after Ukraine declared independence in August 1991, calls for religious independence increased. As discussions with Moscow brought no results, the pro-independence wing led by Filaret assembled an All-Ukrainian Spiritual Consistory composed of bishops, abbots of monasteries and theologians and proclaimed independence in June 1992. ${ }^{6}$ At the same time, the pro-Moscow wing of the Ukrainian Church held an alternative assembly in the eastern part of the country, in Kharkiv, proclaiming that the 'independent' group was heretical and repeating its loyalty to the Moscow Patriarchate (Wasyliw, 2014).

The split resulted in two Churches in Ukraine, namely the Ukrainian Orthodox Church of Kyiv Patriarchate (UOC-KP) led by Patriarch Filaret and the Ukrainian Orthodox Church of Moscow Patriarchate (UOC-MP), the latter holding the status of the ROC eparchy, under the leadership of Metropolitan Volodymyr (Sabodan). The UOC-MP remained the canonical church officially recognized by the Ecumenical Patriarch and other Churches as the most important and widely recognised religious community in Ukraine. The emergence of the UOCKP was further weakened by the recognition of a third and much smaller church, namely the Ukrainian Autocephalous Orthodox Church (UAOC) in 1990. The UAOC allowed the Russian Orthodox Church to present the pro-independence groups as ambitious individuals in search of ecclesiastical power rather than a cohesive national-religious stance. Throughout the 1990s, 
despite having the support of Leonid Kravchuk, the first President of Ukraine, the UOC-KP's call for autocephaly was dismissed by the Ecumenical Patriarchate. However, in subsequent decades, the number of UOC-KP faithful grew steadily.

The issue of autocephaly came into a new light during the 2004 Orange Revolution when President Viktor Yuschenko brought the idea of establishing an independent church back to the political agenda. Despite some initial progress in negotiations between Moscow and Constantinople, autocephaly did not materialise. The UOC-KP adopted a new tactic by considering the possibility of reunion with the UOC-MP which would have enabled ecclesiastical reform. Between 2009 and 2011, Patriarch Filaret and Metropolitan Volodymyr held negotiations on the reunification of their two churches (Interview 11). However, the election of President Viktor Yanukovych in 2010 added pressure to negotiations and the dialogue was halted. Tensions were evident when Metropolitan Volodymyr became ill and hospitalised and the Yanukovych government banned access to him for all of his close advisors.

The 2013 Euro-Maidan demonstrations changed the course of events in the Ukrainian Church. One of the most striking symbolic acts that turned both church and politics upside down was the role played by UOC-KP in the first days of the Euro-Maidan protests in November-December 2013 (Krawchuk and Bremer, 2016; Lunkin, 2014; Wanner, 2015). Apart from political support for the pro-European political course of Ukraine, the Kyiv Patriarchate was the most active publicly in providing direct support to demonstrators. When the Yanukovych government ordered the riot police to repress the protesting students, St Michael Monastery of the Kyiv Patriarchate opened its gates, sheltering the wounded and injured protesters. Its bell rang a sound which resonated with the residents as a signal of fire or foreign invasion. The bell alerted and mobilized thousands of Kyivans, who went to the Independence Square and protested against the regime. Similar scenes were repeated in other cities with hundreds of thousands demonstrating across the country. Over the following months, during the most dramatic phases of the revolution, the Monastery was both a hospital and a burial site for protestors. The UOC-KP's position found support with the masses while the UOC-MP shifted between an openly pro-Russian and an introverted stance. By hosting Patriarch of Moscow Kirill, who often replicated Russia's rhetoric on the decay of Western civilization, the UOC-MP became associated with strong anti-Europeanism. Furthermore, Russia's annexation of Crimea in the aftermath of a local referendum which has been regarded internationally as constitutionally illegal and its military support for the conflict in Donbas greatly affected church-state relations in Ukraine.

After Volodymyr died on 5 July 2014, the top UOC-MP clergy who favoured dialogue with the UOC-KP were replaced while the leadership became dominated by a group of proRussian bishops from eastern and southern Ukraine (Interview 8). Publicly, the UOC-MP refused to take sides in the conflict in Donbas contrasting with the UOC-KP which expressed support for a united Ukrainian statehood. When President Petro Poroshenko took office in June 2014, he tried to entice the Holy Synod of the UOC-MP to elect the pro-independence Metropolitan Symeon (Shostatskiy) of Vynnytsia and Mohyliv-Podilskyi as the new head of the Church. ${ }^{7}$ However, the UOC-MP elected Metropolitan Onufriy (Berezovsky) of Chernivtsi and Bukovyna, who was perceived as a highly spiritual person interested more in liturgy rather than church politics. The UOC-MP's public stance strengthened the state authorities' determination to encourage the course of an independent national church.

\section{Autocephaly, Violence and Political Mobilisation}

When Russia took over Crimea and the conflict in Donbas broke out, churches had to choose between two key questions: 'Was Crimea a Russian or a Ukrainian territory? or 'Was the conflict a civil war or evidence of Russia's invasion of their country?'. These two questions 
are key to understanding the actions of churches and their relations to human security discourses (Wellman and Lombardi, 2012), as would become evident in subsequent years, promoting either violence or reconciliation and tolerance. The UOC-KP unequivocally supported the integrity of Ukrainian statehood. In addition to public statements, ${ }^{8}$ a significant number of clergy enrolled in Ukrainian chaplaincy services. Many others provided support to those who returned from the front lines. The Moscow Patriarchate was hesitant in taking a stance on events taking place in Ukraine. However, in both Crimea and Donbas most priests openly showed their support for the Russian Orthodox Church and in many cases openly supported Kremlin's rhetoric of the 'Russian world'. The eastern region of Ukraine has traditionally been regarded as supporting Russia's influence in the region. Most of its population are Russian speakers who regularly voted for pro-Russian politicians in Ukrainian national elections.

After Russia's takeover of Crimea, the Moscow Patriarchate significantly expanded its direct control over the Crimean eparchy. In June and July 2014, the UOC-MP asked Patriarch Kirill to re-register the Simferopol and Crimea Diocese with Russia's Ministry of Justice. Under the new legislation, Orthodox parishes remained canonically under the UOC-MP; however, in practice Moscow held the veto over the appointment of bishops and decisions taken by the Diocesan Assembly. Most importantly, the Moscow Patriarchate became the main beneficiary of administering church properties using and disposing of them without permission from the UOC-MP. ${ }^{9}$ The UOC-MP leadership in Kyiv did not protest and the lack of public condemnation made the church hierarchs look complicit to a 'land-grab' position. On the other hand, the UOC-KP refused to re-register their parishes with the new authorities arguing that by doing so would recognise Russia's occupation. As a result, clergy were unable to receive Russian citizenship. Most churches were unable to pay utility bills and thus were taken over by the state. In January 2018, only 9 parishes were still open compared to 52 in 2014 (Crimean Human Rights Group. 2018: 25).

In Donbas, the UOC-KP stated loyalty to the Ukrainian state and was gradually forced out of the break-away regions. In autumn 2014, Metropolitan Serhiy (Gorobtsov) of Donetsk and Mariupol had to leave Donetsk and relocated to the government-controlled Mariupol. By contrast, leading UOC-MP bishops reproduced Moscow's narrative stating that the war in Donbas was a civil war between Ukrainian forces without Russia's external intervention. During the conflict, all Orthodox churches were engaged in humanitarian programmes, at times transcending religious divides and working with the Greek Catholic and Protestant churches and Muslim communities (Interviews 5, 7, 10). Churches delivered and distributed water, food and clothing and provided pastoral support to internally displaced peoples not only in the occupied territories but also in other parts of Ukraine.

While a large number of the UPC-KP clergy had to leave, the UOC-MP continued to maintain a significant network of parishes in the Donetsk and Luhansk regions. Metropolitan Illarion (Roman Shukalo) of Donetsk, Metropolitan Mitrofan (Yurchuk) of Luhansk and Alchevsk and Metropolitan Panteleimon of Rovenki (Luhansk region) interacted with and at times even openly supported the separatist authorities. ${ }^{10}$ In December 2017, after Patriarch Kirill met Alexander Zakharchenko and Leonid Pasechnik, the leaders of the Donetsk People's Republic and Lugansk People's Republic, the UOC-MP was involved in the exchange of prisoners with Ukraine releasing 306 prisoners in exchange of 74 people. ${ }^{11}$ The Donbas conflict led even to the emergence of a paramilitary group titled 'the Russian Orthodox Army', although not recognised by or linked to the Russian Orthodox Church, claiming its strong allegiance to Moscow. ${ }^{12}$

The so-called 'buffer zone' between Ukrainian and break-away troops became not only a military area but also a place of religious contestation. The Church which had access to soldiers and the 'buffer zone' was performing a patriotic duty but, more importantly, also 
became stronger at the national level. Church officials have referred to the 'buffer zone' (buferna zona) between military as a 'grey zone' (sira zona) endorsing the idea the area has been disputed not only militarily but also by religious communities (Interviews 9, 11 and 13).

The contrast between how the UOC-KP and the UOC-MP chose to engage with the Donbas conflict and the decision of the Russian Orthodox Church to curtail even further the UOC-MP's rights at a Synod held in Moscow in December 2017 produced dissatisfaction among Ukrainian clergy. ${ }^{13}$ At the same time, as the conflict in Donbas continued, in the winter of 2017, Ukrainian political authorities initiated negotiations between the two non-canonical churches, namely the UOC-KP and the UAOC. The process was met with fierce resistance from the pro-Russian wing. When Metropolitan Makarios (Maletych), head of the UAOC, agreed to start the process of reunification, some of the UAOC bishops met with Ukrainian oligarch Vadym Novynskyi, who moved from Russia to Ukraine in 2012 and was an active sponsor of the UOC-MP. Even though negotiations reached the stage when all UAOC bishops signed a reconciliation petition addressed to the Ecumenical Patriarchate, suddenly the whole process stopped. One interviewee mentioned that accusations were circulating in the corridors of power in Kyiv that the UOAC bishops were offered financial incentives in exchange for revoking their signatures (Interview 3 ).

Unlike previous attempts, when religious and political elites failed to raise the topic of autocephaly with the Ecumenical Patriarchate, in 2018 the situation in the global Orthodox commonwealth was more favourable to Ukraine. There were two major reasons which led the Ecumenical Patriarchate to change its position towards autocephaly: namely, the unprecedented social and political support in Ukraine for an independent Church after 2014 and relations between the Moscow and Constantinople patriarchates, which had deteriorated sharply. The two arguments are discussed in more detail below.

First, the Orthodox Church, and the Kyiv Patriarchate in particular, transformed itself into one of the most respected institutions in Ukrainian society with $56.7 \%$ of the population trusting the Church in 2017. ${ }^{14}$ The request for autocephaly was not only a matter expressed in ecclesiastical circles but also engaged the government and Parliament which officially showed their support.

The Pan-Orthodox Council, a synod of bishops from all Orthodox churches, which has been in preparation since the 1920s and took place in Crete between 19 and 26 June 2016, proved to be not only a theological gathering but also an occasion of geopolitical influence (Leustean, 2018). ${ }^{15}$ Despite participating in previous meetings, at the last minute the Russian Orthodox Church cancelled its participation claiming that it did so due to the fact that the Bulgarian and Georgian Churches had decided not to attend the Council. Although it was not on the agenda, the Ukrainian case was informally present in the debates.

Three days before the opening of the Pan-Orthodox Council, on 16 June 2016, the Ukrainian Parliament (Verkhovna Rada) passed a resolution by a majority of 245 votes asking the Ecumenical Patriarchate to grant autocephaly. ${ }^{16}$ The resolution stated that the Patriarchate should withdraw Moscow's jurisdiction over Ukraine granted in 1686, to convene a council to unify all churches in Ukraine and to grant a Tomos recognising the independence of the Ukrainian national church. This was the Parliament's first resolution on autocephaly; however, it received no response. The Parliament's request which may seem at odds with the separation of state in church in Ukraine denoted political mobilisation in relation to the conflict in Donbas and the changes in Ukraine's territorial integrity. After the Pan-Orthodox Council, the Ecumenical Patriarchate's view of the religious situation in Ukraine changed by becoming more visibly engaged in condemning the violence in Ukraine. On 2 July 2017, Ecumenical Patriarch Bartholomew issued a message in which he deplored the conflict by stating that 'We send our blessing, love and concern for each and every Ukrainian, without any exception. We 
pray for the unity of the Ukrainian people. We pray for peace in Ukraine. Our hope is that fratricidal war will cease'. ${ }^{17}$

The significant shift in the Ecumenical Patriarchate's policy on Ukraine was followed up by Ukrainian political leaders. On 9 April 2018, President Petro Poroshenko went to Istanbul to meet his Turkish counterpart, Recep Tayyip Erdogan, and discuss, in addition to economic cooperation, Turkey's support for the release of Ukrainian political prisoners held in separatistcontrolled territories. ${ }^{18}$ In Istanbul, accompanied by Gennadiy Zubko, Vice-President of the Government of Ukraine, and Pavlo Klimkin, Minister of Foreign Affairs, Poroshenko held a long meeting with Ecumenical Patriarch Bartholomew at which he appealed for the recognition of an independent Ukrainian Church. ${ }^{19}$ The fact that President Poroshenko attended religious services as a parishioner of the UOC-MP showed to the Ecumenical Patriarchate that the quest for autocephaly was not merely an initiative of the UOC-KP, but rather a demand emerging from all segments of Orthodox churches in Ukraine, including those formally affiliated with the UOC-MP. On 17 April 2018, Poroshenko publicly reiterated his support for autocephaly and held meetings with representatives of all Orthodox Churches in Ukraine at which he declared that the new church would not be a 'state church' and that the government should fully respect freedom of religion. ${ }^{20}$ The next day, the bishops of the UOC-KP and the UAOC signed a joint petition addressed to Poroshenko in which they declared their intention to be under the jurisdiction of the Ecumenical Patriarchate. On 19 April 2018, following the President's appeal, the Ukrainian Parliament passed a second resolution by a majority of 268 votes, more than the minimum 226 votes needed, requesting autocephaly. The resolution was opposed by the Opposition Bloc, a political party which emerged in 2014 from President Viktor Yanukovych's Party of Regions and criticised relations with the European Union. Poroshenko praised the resolution as 'restoring historical justice' and argued that this was necessary due to the fact that 'the Kremlin regards the Russian [Orthodox] Church as one of the key tools of influence over Ukraine'. ${ }^{21}$ He hoped that a Tomos recognising independence would be issued by the Ecumenical Patriarchate before the $1030^{\text {th }}$ anniversary of the Christianisation of the Kyivan Rus' which was due to take place on 28 July.

The resolution was discussed at the meeting of the Holy Synod of the Ecumenical Patriarchate on 22 April. The Communique acknowledged that the petition requesting autocephaly was communicated by both legal and civil authorities, which represented millions of Ukrainian Orthodox Christians and announced that a decision would be taken after consultation with the other Orthodox churches. ${ }^{22}$ The announcement made headlines with many commentators predicting an imminent autocephaly proclamation in July. The decision was unprecedented as it officially acknowledged that the Patriarchate was committed to a solution. To emphasise the necessity of reaching an urgent outcome, Patriarch Filaret of the UOC-MP attended a conference at the European Parliament on 3 May 2018 at which he made a passionate plea to stop the violence in Ukraine by stating that 'The war is now there in Donbas, where is my homeland. My native village is occupied by Russia. I know how valuable peace is. And that is why I appeal again and again - the aggressor must be resisted. Because aggression is evil. And reconciliation with evil does not bring peace'. ${ }^{23}$

The second reason that encouraged the Ecumenical Patriarchate to rethink the issue of autocephaly in Ukraine was its competition with the Russian Orthodox Church on canonical primacy in the Orthodox world. The dispute between the two churches was longstanding and became acute in the 1990s when the Ecumenical Patriarchate recognised the Estonian Apostolic Orthodox Church which during the Cold War period was in exile. As a result, the Russian Orthodox Church withdrew from a number of international religious organisations and refused to attend inter-confessional gatherings where the Estonian Church was present. The Moscow Patriarchate, which has been described as 'Russia's secret weapon' (Van Herpen, 2016) has enjoyed support from state authorities both at home and abroad (Curanović, 2012; 
Garrard and Garrard, 2008; Morozova, 2009; Papkova, 2011). Putin has been a regular member, attending religious services. Recognition of his personal role in close church-state relations was visible during his visit to the monastic community of Mount Athos in May 2016 when the religious ceremonial was comparable to that of welcoming a tsar. ${ }^{24}$ After the fall of communism, Russia has advanced the concept of 'spiritual security' in which church and state work together conveying both religious and political messages. Patriarch Kirill and Metropolitan Hillarion, Head of the Department of External Church Relations, have travelled abroad supporting Moscow's geopolitical interests (Hug, 2015; Leustean, 2018; Marsh, 2013; Richters, 2013; Stoeckl, 2014).

\section{Autocephaly, Diplomacy and Social Mobilisation}

The success of President Poroshenko's appeal to the Ecumenical Patriarchate in April 2018 was due to the coordination between religious and state diplomacy. During his visits to other predominantly Orthodox countries Poroshenko met local hierarchs and emphasised his support for an independent Church. ${ }^{25}$ In addition to state diplomacy, the government sent unofficial envoys to the Ecumenical Patriarchate preparing the ground ahead of official declarations. One interviewee mentioned that, between September 2014 and April 2018, Poroshenko's closest advisers travelled twelve times to Istanbul and conducted negotiations behind closed doors (Interview 15).

After the Ecumenical Patriarchate agreed to 'communicate and coordinate' with the other Orthodox Churches regarding the Ukrainian request, the pro-Moscow religious and political bodies launched a significant move against autocephaly via media campaigns, diplomatic channels, public demonstrations and pressure upon clergy. One of the main Ukrainian industrialists, Vadym Novynskyi, used his media resources to present the Ecumenical Patriarchate as an authoritarian structure claiming that the quest for autocephaly was divisive and schismatic. ${ }^{26}$ Novynskyi sought to mobilize congregations in order to demonstrate opposition to autocephaly. On 28 April, the UOC-MP circulated thousands of prefilled petition letters addressed to the Ecumenical Patriarchate which asked 'not to legalize the schism and effectively protested against the creation of an independent national church on the basis of the apostates of the UOC-KP and UAOC,' suggesting that the Church could easily provide one or two million signatures against autocephaly. ${ }^{27}$ On average, around 1,500-2,000 forms were distributed to deaneries and each eparchy received around 20,000 forms. Deaneries were ordered to ensure that parishioners filled in the forms following a standard format. Together with the forms, parishioners received leaflets stating that the autocephaly was a violation of their constitutional rights. As many parishioners failed to sign the letters, the UOCMP extended the campaign until 13 May, re-launching its public visibility. For example, a number of churches in Donbas allowed parishioners to sign multiple letters, ${ }^{28}$ but the Church still fell short of reaching the intended number of signatures.

Even though the campaign was officially orchestrated from Kyiv, there has been no evidence that the campaign had the blessing of Metropolitan Onuphriy, the head of the UOCMP. What became clear was that, instead, opposition to autocephaly represented a faction within the UOC-MP rather than a unitary voice. After meeting President Poroshenko on 17 April, Metropolitan Onufriy refrained from speaking publicly on the anticipated events in the Parliament and at the Ecumenical Patriarchate, a fact which was interpreted as opening his leadership to contestation. The campaign against autocephaly was initiated by one of the most vocal pro-Moscow supporters in Ukraine, Metropolitan Luka (Kovalenko) of Zaporozhe and Melitopol. The day after the Ukrainian Parliament adopted the resolution, the website of the eparchy of Zaporozhe published an 'Alternative Petition to Patriarch Bartholomew' asking not to bestow autocephaly on 'the apostates of the Kyiv Patriarchate'. ${ }^{29}$ Metropolitan Luka was 
one of the most intransigent clerics of the UOC-MP who even refused to provide burial services to people who were previously baptized by clergy from the Kyiv Patriarchate. Within days, the Eparchy of Zaporozhe reported that 10,000 parishioners signed the petition. However, this number contrasted to the eparchies of Vinnitsa, Khmelnitsk, Kamianets-Podilsk in central Ukraine and Ternopil in the west which openly refused to support the campaign.

In a number of cases, public disputes emerged between lower and higher clergy. For example, in the eparchy of Sumy in eastern Ukraine, Metropolitan Evlogiy (Gutchenko) entered into conflict with Nikolay Smakouz, Dean of Sumy, a supporter of autocephaly. Similar situations occurred in other eparchies suggesting that the Moscow Patriarchate relied on informal networks rather than on the ecclesiastical hierarchy. In some Transcarpathian eparchies, priests wrote an open letter to President Poroshenko complaining that they were forced by metropolitans to sign letters of protests against autocephaly 'under the pressure and threats of disobedience and excommunication from the Church'. ${ }^{30}$ This situation pushed the Ecumenical Patriarchate to respond. Acknowledging cases of intimidation, the Ecumenical Patriarchate openly challenged Moscow's statements that Ukraine was its canonical territory. The Patriarchate emphasised that it had only 'conditionally' ceded the right to elect the metropolitan of Kyiv to Moscow in the seventeenth century. In an interview in Kyiv, Father Cyril Hovorun even claimed that the Patriarchate already made a decision on autocephaly and that the text had been written by church canonists as early as May 2018. ${ }^{31}$

Another pressure on the Ecumenical Patriarchate was the attempt of the pro-Moscow wing to organize public protest visits involving journalists and parishioners in Istanbul. In July 2017, a protest took place at the headquarters of the Patriarchate in Istanbul which was widely covered by the Russian mass media as an example of Ukrainian dissatisfaction with autocephaly. In May 2018, the UOC-MP tried to organize a similar event. Officially, the event would have brought together representatives of the Odessa business community to attend an international conference on the topic on the future of Black Sea ports. However, when the real goal of the conference was leaked to the government and the Ecumenical Patriarchate, the event did not take place. ${ }^{32}$

Representatives of the ROC and the UOC-MP visited the capitals of other Orthodox countries trying to persuade local hierarchs not to recognize autocephaly when it would officially be granted. On 4 May, Vadym Novynskyi together with Archbishop Antoniy (Pakanych), Chancellor of the UOC-MP, and Nikolay Danilevich, Deputy Head of the Department for Foreign Relations of the UOC-MP, visited Archbishop Savva of Warsaw, Head of the Polish Autocephalous Orthodox Church. Savva refused to take sides and his Church made a cautious statement on 9 May 2018. On return, the UOC-MP interpreted Savva's statement as supporting the Moscow Patriarchate. However, Savva retracted and issued another statement which indicated that a decision would be made only in observance of church canons. ${ }^{33}$

On 23 June, four metropolitans from the UOC-MP (Metropolitans Agathangelos of Odessa and Izmail, Metropolitan Theodoros of Kamianets-Podilsky and Gorodok, Metropolitan Mitrofanis Luhansk and Alcevsk, Metropolitan Antonios Boryspol and Brovary) accompanied by Vadym Novynskyi visited the Ecumenical Patriarchate presenting their view that the Ukrainian church should stay under Moscow's jurisdiction. ${ }^{34}$ Instead, Ecumenical Patriarch Bartholomew re-emphasised that Constantinople never ceded its jurisdiction. ${ }^{35}$ One of his advisors, Bishop Elpidophoros (Lambriniadis), in an interview with the Russian press agency, described the atmosphere of discussion in the Patriarchate as tense by adding that 'the Moscow Patriarchate is not a mother, but only a daughter of the Ukrainian Church'. ${ }^{36}$

On 25 June, leading bishops of the UOC-MP met at Pechersk Lavra and issued a signed statement that the whole UOC-MP faithful asked the Ecumenical Patriarch not to bestow autocephaly which 'will not cure, but only deepen the split in Ukrainian Orthodoxy, and in 
Ukrainian society as a whole'. ${ }^{37}$ The statement, however, took some bishops by surprise as they did not participate in discussions in Kyiv and did not sign the documents. As a response, a proautocephaly faction within the UOC-MP published an open letter to the Ecumenical Patriarchate which decried Russia's involvement in Donbas stating that 'The Moscow Patriarchate seems to be a Church based in an aggressor state that attacked Ukraine and caused the death of thousands of Ukrainians. The leadership of the UOC-MP is in no way separated from Moscow's religious policy'. ${ }^{38}$ The counter-letter showed that by June 2018, the UOC-MP was split between those who supported the Ecumenical Patriarchate and those who supported Moscow. ${ }^{39}$ At the same time, this internal clash within the UOC-MP benefited the Kyiv Patriarchate.

When it became clear that the Ecumenical Patriarchate was strongly committed to bestowing autocephaly, the Russian Orthodox Church and the UOC-MP sought to block the next stage of negotiations, namely the 'reception' by other national Orthodox churches. Moscow claimed that the Ecumenical Patriarchate could only bestow autocephaly 'in coordination with other sister churches'. Metropolitan Hilarion conducted a series of visits to the leaders of Orthodox Churches in Cyprus (Archbishop Chrysostomos), Egypt (Patriarch Theodoros), Jerusalem (Patriarch Theofilos), Lebanon (Patriarch Ioannis), Romania (Patriarch Daniel) and Poland (Metropolitan Savva). In addition, the ROC requested that bishops located in European capitals run activities in support of Russia's jurisdiction in Ukraine and portray the oppression of the Ukrainian Church by political authorities. The Church's diplomacy was supported by state authorities in those countries. On 18 May 2018, Archbishop Antoniy (Sevryuk) of Vienna and Budapest met Metropolitan Presow of Czech and Slovak Lands to discuss the religious and political situation in Ukraine. On 8 June, Sergei Gavrilov, Head of the Russian Parliament's Committee for the Development of Civil Society and Religious Communities, together with several Russian businessmen went to Athens and took part in the Holy Synod of the Orthodox Church of Greece. ${ }^{40}$ In July 2018, Patriarch of Moscow Kirill and two more delegations met leaders of the Ecumenical Patriarchate, Bulgarian and Albanian Orthodox Churches and asked for their support. ${ }^{41}$ At this stage the competition between Moscow and Constantinople was visible even in sermons. After a religious service anointing a new bishop in Switzerland, Patriarch Bartholomew directly criticised the Russian Orthodox Church stating that Russia's diplomacy was not beneficial and that 'formerly atheist powers are trying to slander the Ecumenical Patriarchate'. ${ }^{42}$

In addition to Russian diplomacy, Ukrainian authorities made efforts to secure the support of other Orthodox churches. From April to August 2018, Ukrainian ambassadors in Poland, Cyprus, Serbia and Greece met local hierarchs; on 26 and 29 May, Andrei Parubiy, Speaker of the Ukrainian Parliament, visited the Georgian Orthodox Church and the Jerusalem Patriarchate; on 29 May, Pavlo Klimkin, Ukraine's Foreign Minister visited Patriarch Theofil III in Jerusalem; on 30 May, former Presidents Leonid Kravchuk and Leonid Kuchma visited Metropolitan Rastislav of the Czech and Slovak lands; and on 15 June, Rostyslav Pavlenko, Deputy Head of the Presidential Administration, visited Patriarch Neofit of the Bulgarian Orthodox Church. ${ }^{43}$

Most Orthodox churches supported Ukraine's intention to create its own national Church with the Polish and Greek Orthodox Churches openly supporting the Ecumenical Patriarch as the 'mother church' of Ukraine. The only exception was the Serbian Orthodox Church which reproduced Moscow's narrative calling the UOC-MP a 'martyr church' which suffered due to the Kyiv political regime. ${ }^{44}$ Belgrade's support for Moscow was anticipated due to their long-standing relations. In February 2018, the Russian Foreign Minister, Sergei Lavrov and Metropolitan Hilarion, together with Serbian religious and political leaders unveiled a mosaic in the dome of the Church of Saint Sava in Belgrade, one of the largest Orthodox churches in Europe. The mosaic was a gift from Gazprom, Russia's largest energy 
company. The Serbian Orthodox Church has faced its own internal disputes on the autocephaly of the Macedonian Orthodox Church, a dispute dating back to the 1960s. On 23 May 2018, as a sign of gratitude for his stance in the Orthodox commonwealth, the Patriarch of Serbia was awarded the Prize for Outstanding Services to the Unity of Orthodox People at a ceremony held in Moscow. ${ }^{45}$ In addition, the Patriarchate of Antioch explicitly supported Moscow following Russia's involvement in the Syrian conflict. ${ }^{46}$ Other churches have either openly supported autocephaly or refrained from taking sides, a gesture which was interpreted as tacitly approving the Ecumenical Patriarchate. In a number of cases national hierarchies have been split. For example, while the leadership of the Georgian Orthodox Church has formally kept silence, a few bishops have supported Ukraine by issuing their own individual statements.

Even the Orthodox Church of Greece, which has traditionally had good relations with Moscow and 'fraternal competition' with Constantinople, has been frustrated by Russia's method of conducting foreign policy in the Balkans. In July 2018, Greece finally reached a solution for the long-standing dispute over the name of its neighbouring country, the Former Yugoslav Republic of Macedonia, which could open the door to NATO membership. Russia sought to prevent these developments and tried to bribe Macedonian nationalists to stop the deal. ${ }^{47}$ As a result, Greece announced as persona non-grata two Russian diplomats and two other Russian officials associated with the Imperial Orthodox Palestine Society (IOPS). In addition, the number of visas issued to Russian clergy traveling to Greece and Mountain Athos was limited while the cash-flow from Russia to Athos monasteries came under investigation. ${ }^{48}$ In a harsh tone, the Foreign Ministry's statement on 10 August 2018 pointed out that Russia tried "to impose the presence of the "Imperial Orthodox Palestine Society" in Greece, an organization created by the Czars' secret services in the 19th century with a view to deHellenize the patriarchates of the Middle East' ${ }^{49}$ The IOPS was re-established by the Russian Parliament in 1992 and currently has fourteen offices in the Middle East and Europe, including Greece since $2016 .^{50}$ The IOPS has been an active promoter of Russia's foreign policy since 2007 when Sergei Stepashin, former Prime Minister and the first Head of the Federal Security Service and Federal Counter-Intelligence, was appointed its president. ${ }^{51}$

In Ukraine, in order to increase its own visibility, the pro-Russian wing organised public processions under slogans of church unity. With Ukraine preparing to celebrate the $1030^{\text {th }}$ anniversary of its conversion to Christianity, on 27 July, the UOC-MP brought to Kyiv parishioners and clergy by buses hired or owned by businesses affiliated with Vadym Novynskiy. Demonstrators walked through the centre of Kyiv to express their loyalty and spiritual bond with the Moscow Patriarchate. The procession was led by Metropolitan Onufriy, who had kept a low profile until then. The Ministry of Internal Affairs stated that around 20,000 people attended the demonstration, contrasting with the UOC-MP's figure of around 200,000. The pro-autocephaly church wing headed by President Poroshenko and Patriarch Filaret of the UOC-KP organized an alternative procession the following day, with official figures at around 65,000 people. $^{52}$

When all efforts to prevent the autocephaly process failed, on 28-29 August, Patriarch Kirill and Metropolitan Hilarion travelled to the Ecumenical Patriarchate in Istanbul. After two hours of meetings behind closed doors, Kiril returned to Moscow without issuing an official statement. Instead, Ecumenical Patriarch Bartholomew reiterated his positive attitude towards Ukrainian autocephaly. Two days later, on 1 September 2018, at a meeting of the senior bishops of the Ecumenical Patriarchate (Synaxis), Bartholomew presented a detailed report on the church situation in Ukraine. The report was the most explicit document to challenge Moscow's position that it had continuous jurisdiction over Ukraine by referring back to the fourteenth century and stating that, 


\begin{abstract}
'Already from the early $14^{\text {th }}$ century, when the see of the Kyivan Metropolis was moved without the canonical permission of the Mother Church to Moscow, there have been tireless efforts on the part of our Kyivan brothers for independence from ecclesiastical control by the Moscow centre. Indeed, the obstinacy of the Patriarchate of Moscow was instrumental in occasionally creating repeated mergers and restorations of ecclesiastical eparchies, uncanonical elections of Bishops as well as schisms, which still afflict the pious Ukrainian people.

However, beyond all this, a study of the matter in the light of the sacred canons does not justify any intervention whatsoever by the Church of Russia. The Tome proclaiming Moscow as a Patriarchate does not include the region of today's Metropolis of Kyiv in the jurisdiction of Moscow. Moreover, after the well-known manner of proclamation of Moscow as a Patriarchate by Ecumenical Patriarch Jeremiah II (Tranos), the canonical dependence of Kyiv to the Mother Church of Constantinople remained constant and uninterrupted. In the year 1686, our predecessor, the late Patriarch Dionysios IV, following great political pressure from the harrowing circumstances and for peace in the local Church, was obliged to issue a letter granting Moscow the license to ordain the Metropolitan of Kyiv on the inviolable condition that every Metropolitan of Kyiv would commemorate the name of the Ecumenical Patriarch as his ecclesiastical superior and authority, but also to demonstrate the canonical jurisdiction of Constantinople over this Metropolis'. ${ }^{53}$
\end{abstract}

The report created a legal justification for bestowing autocephaly by stating that the Ecumenical Patriarchate was able to do so without approval from any other Churches. This position ensured that Moscow's attempt to mobilize other Churches against its decision became more difficult (Interview 16).

Two days after the Synaxis, Bartholomew appointed two Exarchs (representatives) from the Ecumenical Patriarchate to Ukraine, namely Archbishop Daniel (Zelinsky) of Pamphilon from the Ukrainian Orthodox Church of the United States and Bishop Hilarion (Rudnyk) of Edmonton from the Ukrainian Orthodox Church of Canada. Both of them were ethnic Ukrainians, born in the western part of the country, who were engaged in the first negotiations between Ukrainian churches. The very fact of their appointment seemed to suggest official recognition of the independence of the Ukrainian Church. In the announcement, the Ecumenical Patriarchate mentioned that the appointments took place in the framework of the 'already decided bestowal of autocephaly' (apofaseistheisa autokefalaia). The Moscow Patriarchate called an emergency meeting of its Holy Synod and deplored the decision as an invasion to its canonical territory. Moscow accused the Ecumenical Patriarchate of falsifying historical facts ${ }^{54}$ and criticised Constantinople for trying to re-shape the Orthodox community following the Catholic model in which final authority resides in Rome. ${ }^{55}$ As a result, on 14 September, Moscow interrupted Eucharistic communion with the Ecumenical Patriarchate, refused to attend 'inter-orthodox episcopal assemblies, inter-Christian theological dialogues and other commissions or structures chaired by representatives of the Ecumenical Patriarchate' and declared that the Ecumenical Patriarchate's decision was anti-canonical.

A few weeks later, the Ecumenical Patriarchate's stance became clearer. Three days after another Synaxis of the Ecumenical Patriarchate, on 11 October, Metropolitan Emmanuel of France stood on the steps of the Patriarchal Palace and read the decision of the Holy Synod. The statement was divided into five points, namely that 1) 'To renew the decision already made that the Ecumenical Patriarchate proceed to the granting of Autocephaly to the Church of Ukraine', 2) to re-establish its presence and jurisdiction (Stavropegion) in Kyiv, 3) to recognise the hierarchs of the Ukrainian Orthodox Church - Kyiv Patriarchate and the Ukrainian Autocephalous Orthodox Church in communion with the wider Orthodox commonwealth, 4) 
'To revoke the legal binding of the Synodal Letter of the year 1686, issued for the circumstances of that time, which granted the right through oikonomia to the Patriarch of Moscow to ordain the Metropolitan of Kyiv' and 5) 'To appeal to all sides involved that they avoid appropriation of Churches, Monasteries and other properties, as well as every other act of violence and retaliation'. ${ }^{56}$

The declaration that the Moscow Patriarchate's jurisdiction over Kyiv had been revoked represented a major rupture between the Russian Orthodox Church and the Ecumenical Patriarchate. On 15 October, Kirill organised a Synod in Minsk which reiterated that Moscow and Constantinople were no longer in communion. By choosing to hold it in Minsk rather than Moscow, the Russian Orthodox Church presented the image that the other Orthodox communities under its jurisdiction remained united, particularly in countries and territories where Orthodox churches may also aspire to become independent, such as in Belarus, Moldova and South Ossetia. The Orthodox Churches in the former Soviet states of Kazakhstan, Kyrgyzstan and Tajikistan also stated their intention to severe ties with Constantinople. ${ }^{57}$ Failure to stop the Ecumenical Patriarchate's decision was seen immediately. Moscow shuffled some of his hierarchs abroad by asking Bishop John (Roshchin) in charge of parishes under Moscow's jurisdiction in the United States to administer the Russian faithful in Italy, while Bishop Matthew of Sourozh from the Russian Orthodox Church's diocese in Great Britain and Ireland took over his role in the United States. At the same time, Archbishop Antonius of Vienna and Budapest was removed from his post with no statement made regarding his new position. ${ }^{58}$ In Istanbul, after the 11 October declaration, the Ecumenical Patriarchate turned again towards Donbas. That the issue of violence has continued to remain at the core of the Ecumenical Patriarchate's decision to support autocephaly was symbolically present, when, on 18 October 2018, Bartholomew welcomed to his Patriarchal Palace some children of Ukrainian military who died in Donbas. ${ }^{59}$ A few months later, in a symbolic ceremony at the headquarters of the Ecumenical Patriarchate, on 6 January 2019, Bartholomew offered the Tomos of autocephaly to the Ukrainian Orthodox Church.

\section{Conclusion}

The quest for religious independence pursued by Ukraine has indicated several trends in church-state relations in Eastern Europe. First of all, in most predominantly Orthodox countries, an independent church has a strong symbolic value with state independence being presented as unaccomplished without autocephaly. Second, the Ukrainian autocephaly debate has demonstrated that institutions, either religious or political, have adapted to social trends. Although the UOC-KP was a non-recognized church with marginal access to religious sites and public spaces, its congregations increased steadily. Despite its uncertain status, the engagement of the UOC-KP faithful and clergy in condemning acts of violence during the Euro-Maidan protests and the conflict in Donbas increased its legitimacy both for ordinary people and political leaders. Patriarch Filaret's statements on the European Union and condemning the violence in Donbas added to his Church's engagement with the masses. Another example of discontinuity between formal institutions and social trends is the fact that while many members of the Ukrainian political elite are parishioners of the UOC-MP, they have not hesitated to show their support for autocephaly. The UOC-KP came to be regarded as providing support to state territoriality, namely Ukraine's right as an independent subject and not as part of the wider Russian world. Third, the change in the Ecumenical Patriarchate's position towards Ukraine has been attributed to the close engagement of religion and politics during Putin's regime. Moscow has claimed leadership of the Eastern Orthodox world by relying on the size of its population, the notion of spiritual security and church-state relations. The Ecumenical Patriarchate was prepared to escalate tensions with the Moscow Patriarchate, 
suggesting that, from his perspective, the case of Ukraine was geopolitically strategic for the future of Eastern Orthodoxy. Moscow's fears that other Orthodox communities under its jurisdiction, such as in Belarus, Moldova or South Ossetia, could follow suit and declare their independence, was key to the ways in which churches behaved in international affairs.

While welcomed by many clergy and faithful, the autocephaly debate has also brought unease in Ukraine. We argue that two final conclusions remain open for future debates. First, President Poroshenko's close involvement in the autocephaly debates has been perceived as an electoral tool mobilizing the masses ahead of the 2019 elections. While autocephaly was a fundamental step to strengthening of the Ukrainian statehood, as Nicolai N. Petro has shown, Poroshenko's attempt to instrumentalize this achievement was counterproductive. ${ }^{60}$ Metropolitan Epiphany's close support of Poroshenko, who adopted a mixture of religious and war narratives in his electoral slogan ('Language, Faith, Army'), undermined the public legitimacy of the newly-created Church. Corruption scandals surrounding Poroshenko's associates and the presence of controversial business figures in Epiphany's entourage reduced Poroshenko's chances of success. Internal disputes between top hierarchs regarding the dayto-day management of the Church further increased his negative image. Archbishop Clement of Simferopol and Crimea even issued a public statement asking Patriarch Filaret to meet Metropolitan Epiphany to alleviate the situation, stating that 'the President of Ukraine, people's deputies, members of the government, officials of different levels [should] stop interfering in the internal church life'. His words came in contrast to the human security crisis which led to the nascent of the new Church, namely the conflict in eastern Ukraine which affected thousands of people. Clement deplored the fact that since the Tomos was issued in January state authorities were no longer interested in the fate of his community. ${ }^{61}$

Unsurprisingly, the political instrumentalisation of religion and church tensions led to public mockery which was capitalised by comedian Volodymyr Zelensky, who distanced from the other candidates and became Poroshenko's main contender in the presidential race. Holding the religious card enabled Poroshenko to reach the second round, however; it was not enough to stop Zelensky who attracted $73.22 \%$ of the votes. In his first speech congratulating the new president, Patriarch Filaret made reference to the role played by the Church in supporting the state pointing out that the Church's aim was 'to consolidate pro-Ukrainian and state forces in Ukraine'. ${ }^{62}$

Lastly, and most importantly, autocephaly has led to the politicization of Orthodoxy along ethnic lines in Ukraine, as evident when the Ukrainian Parliament demanded that the UOC-MP re-register under a new name, 'the Russian Orthodox Church in Ukraine'. What is Russian? What is Ukrainian? Could the 'Russian Orthodox Church in Ukraine' be completely removed from Ukrainian identity and the state-building process? These questions remain highly debated and particularly poignant as the majority of the UOC-MP's flock is not ethnically Russian and see their religious affiliation closely connected with Ukrainian state integrity.

The continued politicisation of religion could support 'low-intensity conflicts' as recently suggested by Malyarenko and Wolff (2018). At times, clergy from the Kyiv Patriarchate, in both eastern and western parts of the country, have used a similar type of divisive rhetoric to those from the Moscow Patriarchate. Some clergy demanded the transfer of church property from the UOC-MP to the UOC-KP. Even if the government has repeatedly rejected the repartition of properties, a number of bishops and clergy took the matter in their own hands and appropriated churches and parishes. Efforts to identify the exact number of people and parishes which take one side or the other have remained unreliable and vary widely, with each Church producing its own figures. The issue of violence continues to haunt the political spectrum, as already indicated in the Ecumenical Patriarchate's statement on 11 October 2018. ${ }^{63}$ The government has planned to conduct a series of roundtable and media 
campaigns informing the faithful on church matters and to organise a preliminary assembly of bishops which should draft a concordat on the independent national church and church-state relations.

The autocephaly debate in Ukraine will continue in the years to come, most likelyleading to discordant statements from church and political leaders across Eastern Europe and the former Soviet states. It will also most likely advance the geopolitical polarisation of Eastern Christianity with some Orthodox Churches siding with the Ecumenical Patriarchate and others with Moscow.

\section{References}

Angold, Michael (ed.). 2006. The Cambridge History of Christianity. Volume 5: Eastern Christianity. Cambridge: Cambridge University Press.

Bertelsen, Olga (ed.). 2016. Revolution and War in Contemporary Ukraine: The Challenge of Change. Stuttgart: Ibidem-Verlag,

Bociurkiw, Bohdan R. 1990. 'The Rise of the Ukrainian Autocephalous Orthodox Church, 1919-1922' in Geoffrey A. Hosking (ed.), Church, Nation and State in Russia and Ukraine, Edmonton: Canadian Institute of Ukrainian Studies Press, 228-249.

Bociurkiw, Bohdan R. 1996. The Ukrainian Greek Catholic Church and the Soviet State (19391950). Toronto: Canadian Institute of Ukrainian Studies Press.

Crimean Human Rights Group. 2018. Freedom of Religion and Beliefs in Crimea: Analytical Review on Situation Regarding Freedom of Religion and Beliefs in Occupied Crimea (April 2014 - January 2018), Kyiv. At https://crimeahrg.org/wpcontent/uploads/2018/04/Religion_EN.pdf

Curanović, Alicja. 2012. The Religious Factor in Russia's Foreign Policy. London: Routledge.

Demacopoulos, George E. and Aristotle Papanikolaou (eds). 2013. Orthodox Constructions of the West. New York: Fordham University Press.

Denysenko, Nicholas E. 2014. 'Chaos in Ukraine: The Churches and the Search for Leadership', International Journal for the Study of the Christian Church, 14 (3), 242-59.

Dragneva, Rilka and Kateryna Wolczuk. 2015. Ukraine between the EU and Russia. New York: Palgrave Pivot Book.

Elliott, Mark R. (ed.). 2014. The Impact of the Ukrainian Crisis on the Church and Christian Ministry. Special issue of East-West Church and Ministry Report 22:3. Wilmore, KY: Asbury University.

Fagan, Geraldine. 2013. Believing in Russia - Religious Policy after Communism. New York: Routledge.

Fylypovych, L. O. and O. V. Horkusha (eds.). 2015. Maidan i Tserkva. Khronika podii ta ekspertna otsinka. $2^{\text {nd }}$ ed. Kyiv: Sammit Knyha. 
Garrard, John and Carol Garrard. 2008. Russian Orthodoxy Resurgent: Faith and Power in the New Russia. Princeton: Princeton University Press 2008

Gerd, Lora. 2018. 'Russian Imperial Policy in the Orthodox East and Its Relations to Byzantine Studies' in Alena Alshanskaya, Andreas Gietzen and Christina Hadjiafxenti (eds.), Imagining Byzantium: Perceptions, Patterns, Problems, Mainz: Verlag des Römisch-Germanischen Zentralmuseums, 2018, pp. 93-98.

Himka, John-Paul. 1999. Religion and Nationality in Western Ukraine. The Greek Catholic Church and the Ruthenian National Movement in Galicia, 1870-1900, Montreal: Queen's University Press.

Hug, Adam (ed.). 2015. Traditional Religion and Political Power: Examining the Role of the Church in Georgia, Armenia, Ukraine and Moldova. London: The Foreign Policy Centre

Kazmina, Olga and Olga Filippova. 2005. 'Re-Imagination of Religion in Post-Soviet Society: Challenges and Responses (Russian and Ukrainian Case Studies)', Journal of the American Academy of Religion, 73, 1051-1076.

Kozelsky, Mara. 2014. 'Religion and the Crisis in Ukraine', International Journal for the Study of the Christian Church, 14 (3), 219-41

Krawchuk, Andrii and Thomas Bremer (eds.). 2016. Churches in the Ukrainian Crisis, Basingstoke: Palgrave.

Leustean, Lucian N. (ed.). 2018. Eastern Christianity and Politics in the Twenty-First Century, London: Routledge.

Leustean, Lucian N. 2018, 'Eastern Orthodoxy, Geopolitics and the 2016 'Holy and Great Synod of the Orthodox Church", Geopolitics, 23 (1), 201-216.

Lunkin, Roman. 2014. 'The Ukrainian Revolution and Christian Churches' in Special Issue on 'A Theme Issue on the Impact of the Ukrainian Crisis on the Church and Christian Ministry, East-West Church and Ministry Report, 22 (3), 1-5

Malyarenko, Tatyana and Stefan Wolff. 2018. 'The Logic of Competitive Influence-Seeking: Russia, Ukraine, and the Conflict in Donbas', Post-Soviet Affairs, 34 (4), 191-212.

Mavelli, Luca and Erin K. Wilson (eds.). 2017. The Refugee Crisis and Religion. Secularism, Security and Hospitality in Question. London: Rowman \& Littlefield.

Christopher Marsh. 2013. 'Eastern Orthodoxy and the Fusion of National and Spiritual Security' in Chris Seiple, Dennis R. Hoover and Pauletta Otis (eds.), The Routledge Handbook of Religion and Security. London: Routledge, 22-32.

Mearsheimer, John J. 2014. 'Why the Ukraine Crisis is the West's Fault: The Liberal Delusions That Provoked Putin'. Foreign Affairs 93 (5): 77-89.

Mitrokhin, Nikolai. 2010. 'Orthodoxy in Ukrainian Political Life, 2004-2009', Religion, State and Society, 38 (3), 229-251. 
Morozova, Natalia. 2009. 'Geopolitics, Eurasianism and Russian Foreign Policy under Putin', Geopolitics, 14 (4), 667-86.

Papkova, Irina. 2011. The Orthodox Church and Russian Politics. New York: Oxford University Press.

Petro, Nicolai N. (ed.). 2017. Ukraine in Crisis. New York: Routledge.

Pew Research Centre. 2017. Religious Belief and National Belonging in Central and Eastern Europe. At http://www.pewforum.org/2017/05/10/religious-belief-and-national-belonging-incentral-and-eastern-europe/

Plokhy, Serhii and Frank E. Sysyn, 2003. Religion and Nation in Modern Ukraine. Edmonton: Canadian Institute of Ukrainian Studies Press.

Plokhy, Serhii. 2015. The Gates of Europe: A History of Ukraine. London: Allen Lane.

Prodromou, Elizabeth. 2004. 'The Ambivalent Orthodox', Journal of Democracy, 15 (2), 6275.

Ramet, Pedro (ed.). 1988. Eastern Christianity and Politics in the Twentieth Century. Durham and London: Duke University Press.

Richters, Katja. 2013. The Post-Soviet Russian Orthodox Church: Politics, Culture and Greater Russia, London: Routledge.

Roudometof, Victor. 2013. Globalization and Orthodox Christianity. The Transformation of a Religious Tradition. London: Routledge.

Samokhvalov, Vsevolod. 2015. 'Ukraine between Russia and the European Union: Triangle Revisited'. Europe-Asia Studies 67 (9): 1371-1393

Samokhvalov, Vsevolod. 2017. Russian-European Relations in the Balkans and Black Sea Region: Great Power Identity and the Idea of Europe, Basingstoke: Palgrave.

Senyk, Sophia. 1993. A History of the Church in Ukraine. Vol. 1: To the End of the Thirteenth Century. Rome: Pontificio Istituto Orientale.

Senyk, Sophia. 2011. A History of the Church in Ukraine. Volume 2: 1300 to the Union of Brest. Rome: Pontificio Istituto Orientale.

Simons, Greg. 2015. 'Religious Diplomacy in International and Inter-Orthodox Relations' in Greg Simons and David Westerlund (eds.), Religion, Politics and Nation-Building in PostCommunist Countries, Farnham: Ashgate, 21-44.

Stoeckl, Kristina, 2014. The Russian Orthodox Church and Human Rights. London: Routledge.

Sysyn, Frank E. 2003. 'The Third Rebirth of the Ukrainian Autocephalous Orthodox Church and the Religious Situation in Ukraine, 1989-1991' in Serhii Plokhy and Frank E. Sesyn (eds.), 
Religion and Nation in Modern Ukraine, Edmonton: Canadian Institute of Ukrainian Studies Press, pp. 88-119.

Van der Laarse, Rob, Mykhailo Cherenkov, Vitaliy V. Proshak, and Tetiana Mykhalchuk (eds.). 2015. Religion, State, Society, and Identity in Transition: Ukraine, Oisterwijk, The Netherlands: Wolf Legal Publishers.

Van Herpen, Marcel H. 2016. Putin's Propaganda Machine. Soft Power and Russian Foreign Policy. Lanham: Rowman \& Littlefield.

Wanner, Catherine (ed.) 2012. State Secularism and Lived Religion in Soviet Russia and Ukraine. New York: Woodrow Wilson Center Press and Oxford University Press.

Wanner, Catherine (ed.). 2015. Religion and Political Crisis in Ukraine. Special Issue of Euxeinos. Governance and Culture in the Black Sea Region 17. St Gallen, CH: University of St Gallen.

Wasyliw, Zenon V. 2014. 'Orthodox Churches in Ukraine' in Lucian N. Leustean (ed.), Eastern Christianity and Politics in the Twenty-First Century, London: Routledge, 312-33.

Wellman, James K., Jr. and Clark B. Lombardi (eds.), 2012. Religion and Human Security: A Global Perspective. Oxford: Oxford University Press.

Wilson, Andrew. 2000. The Ukrainians. Unexpected Nation. New Haven: Yale University Press.

Wilson, Andrew. 2014. Ukraine Crisis: What It Means for the West. New Haven: Yale University Press.

Wood, Elizabeth A., William Pomeranz, E. Wayne Merry, and Maxim Trudolyubov. 2016. Roots of Russia's War in Ukraine. New York: Woodrow Wilson Center Press and Columbia University Press.

Yekelchyk, Serhy. 2015. The Conflict in Ukraine: What Everyone Needs to Know. New York: Oxford University Press.

Appendix. List of interviews ${ }^{64}$

\begin{tabular}{|l|r|}
\hline Anonymized interlocutor & Reference \\
\hline $\begin{array}{l}\text { Academic, the National Academy of } \\
\text { Sciences of Ukraine }\end{array}$ & Interview 1 \\
\hline $\begin{array}{l}\text { Academic, the National Academy of } \\
\text { Sciences of Ukraine }\end{array}$ & Interview 2 \\
\hline $\begin{array}{l}\text { Department for Religious Affairs and } \\
\text { Nationalities, Ministry of Culture of Ukraine }\end{array}$ & Interview 3 \\
\hline Gender Budgeting in Ukraine Project, Kyiv & Interview 4 \\
\hline $\begin{array}{l}\text { Representation of the European Union in } \\
\text { Ukraine }\end{array}$ & Interview 5 \\
\hline Journalist & Interview 6 \\
\hline
\end{tabular}




\begin{tabular}{|l|r|}
\hline $\begin{array}{l}\text { Humanitarian and Emergency Programmes, } \\
\text { Caritas Ukraine }\end{array}$ & Interview 7 \\
\hline $\begin{array}{l}\text { Ukrainian Orthodox Church - Moscow } \\
\text { Patriarchate official }\end{array}$ & Interview 8 \\
\hline $\begin{array}{l}\text { Ukrainian Orthodox Church }- \text { Moscow } \\
\text { Patriarchate official }\end{array}$ & Interview 9 \\
\hline $\begin{array}{l}\text { Ukrainian Orthodox Church }- \text { Moscow } \\
\text { Patriarchate official }\end{array}$ & Interview 11 \\
\hline $\begin{array}{l}\text { Ukrainian Orthodox Church - Moscow } \\
\text { Patriarchate official }\end{array}$ & Interview 12 \\
\hline Academic, Kyiv Theological Academy & Interview 13 \\
\hline $\begin{array}{l}\text { Ukrainian Orthodox Church - Kyiv } \\
\text { Patriarchate official }\end{array}$ & Interview 14 \\
\hline $\begin{array}{l}\text { Ukrainian Orthodox Church - Kyiv } \\
\text { Patriarchate official }\end{array}$ & Interview 15 \\
\hline Presidential Administration official & Interview 16 \\
\hline $\begin{array}{l}\text { Ecumenical Patriarchate of Constantinople } \\
\text { official }\end{array}$ & \\
\hline
\end{tabular}

\section{Notes}

1 'Patriarch Kirill: ROC will never agree to independence of Ukrainian Church', Religious Information Service of Ukraine, 21 November 2016 at https://risu.org.ua/en/index/all news/orthodox/moscow patriarchy/65197/.

${ }^{2}$ The fourteen Orthodox churches in communion are 1. The Ecumenical Patriarchate, Turkey; 2. The Greek Orthodox Patriarchate of Alexandria, Egypt; 3. The Greek Orthodox Patriarchate of Antioch, Syria; 4. The Greek Orthodox Patriarchate of Jerusalem, Israel; 5. The Russian Orthodox Church; 6. The Serbian Orthodox Church; 7. The Romanian Orthodox Church; 8. The Bulgarian Orthodox Church; 9. The Georgian Orthodox Church; 10. The Orthodox Church of Cyprus; 11. The Orthodox Church of Greece; 12. The Orthodox Autocephalous Church of Albania; 13. The Polish Orthodox Church; and 14. The Orthodox Church in the Czech Lands and Slovakia. The Orthodox Church of America is not included here as its autocephaly is disputed by some churches.

3 'Letter to His Excellency Mr. Petro Poroshenko, President of Ukraine' (in Bulgarian), 12 June 2017, at https://bg-patriarshia.bg/news.php?id=237118

${ }^{4}$ Cynthia Buckley, Ralph Clem, Jarod Fox and Erik Herron, 'The war in Ukraine is more devastating than you know', The Washington Post, 9 April 2018.

${ }^{5}$ The UNHCR data on Ukraine at http://www.unhcr.org/ua/en/internally-displaced-persons .

6 'Appeal of the Hierarchs of the Ukrainian Orthodox Church to His Holiness Patriarch of Moscow and All Rus' Aleksi II, The Holy Synod and All the Hierarchs of the Russian Orthodox Church' (in Russian), December 1991, at: https://www.ec-patr.org/deltiotypou/ukraine/aitimab-aftokef-ukr.pdf

7 'One against all. What is known about the only Metropolitan who did not support the break of the UOC MP with Constantinople' (in Ukrainian), Novaya Volna, 15 November 2018, at: https://nv.ua/ukr/ukraine/events/odin-proti-vsikh-shcho-vidomo-pro-jedinij-mitropolita-nepidtrimali-rozriv-upts-mp-z-konstantinopolem-2507031.html

8 'Filaret: The Lord helps in the growth of the Kiev Patriarchate' (in Ukrainian), 1 August 2018, at: http://ual.com.ua/society/filaret-gospod-dopomagae-v-zrostanni-kijivskogo-patriarhatuvin-dopustiv-viynu-45193.html 
${ }^{9}$ Yuri Alexandrov, 'Church annexation of the Crimea: UOC of the Moscow Patriarchate gave its Crimean dioceses and their property to the Russian Orthodox Church' (in Russian), Crimea. Realia (Radio Free Europe/Radio Liberty), 9 May 2015, at https://ru.krymr.com/a/26889260.html

${ }^{10}$ Tatyana Derkach, 'Cossaks-Bandits: Private Military Companies at the service of the UOCMP. Chapter 11: Eparchy of Luhansk' (in Russian) at: https://petrimazepa.com/kazaki_razboiniki_cvk_na_sluzbe_u_upc_mp_cast_11_luganskaa_e parhia and 'Chapter 13' at Eparchy of Rovenki' (in Russian) at https://petrimazepa.com/kazaki razboiniki cvk_na sluzbe u upc mp cast 13 rovenkovska a eparhia

11 'Patriarch Kirill meets with Zakharchenko, Pasechnik and Medvedchuk', The Russian Orthodox Church's Department of External Church Relations, 25 December 2017 at https://mospat.ru/en/2017/12/25/news155097/

12 Shaun Walker and Alec Luhn, 'Ukraine separatists vow to fight on as president unveils ceasefire plan', The Guardian, 19 June 2014 at https://www.theguardian.com/world/2014/jun/18/ukraine-president-ceasefire-plan-vladimirputin

13 'Decision of the Holy Assembly of the Hierarchs of the Russian Orthodox Church "On Amendments and Additions to the Status of the Russian Orthodox Church and other Documents of the Russian Orthodox Church"'(in Russian), 30 November 2017, at http://www.patriarchia.ru/db/text/5074390.html; For critical review see Alexander Drabinko, Metropolitan of Pereyaslav-Khmelnitsky and Vishnevsky, On the independence of the Ukrainian Church, (in Russian), Levy Bereg, 2 December 2017, https://lb.ua/society/2017/12/02/383617 nezavisimosti_ukrainskoy tserkvi.html

14 The Kiev International Institute of Sociology, 'Press Release' (in Ukrainian), 1 February 2017, at: http://www.kiis.com.ua/?lang=ukr\&cat=reports\&id=678.

15 The website of The Holy and Great Council of the Orthodox Church is available at https://www.holycouncil.org/

16 'Appeal of the Verkhovna Rada of Ukraine to His Holiness Bartholomew, Archbishop of Constantinople and New Rome, Ecumenical Patriarch, to bestow autocephaly to the Ukrainian Orthodox Church in Ukraine' (in Ukrainian), 19 June 2016, at http://zakon.rada.gov.ua/laws/show/1422-19.

17 'Message by His All-Holiness Ecumenical Patriarch Bartholomew to Ukrainian Journalists' at https://www.patriarchate.org/message/-/asset publisher/yYvX9I5UvsXD/content/messageby-his-all-holiness-ecumenical-patriarch-bartholomew-to-the-association-of-ukrainianjournalists-venerable-patriarchal-church-of-saint-george-/

18 'The President of Ukraine held a meeting with the President of Turkey in Istanbul', The Official Website of the President of Ukraine (in Ukrainian), 9 April 2018, at http://www.president.gov.ua/ru/news/prezident-ukrayini-u-stambuli-proviv-zustrich-zprezidentom-46806

19 The Ecumenical Patriarchate was represented in the meeting by Metropolitans John of Pergamon, Epidophoros of Proussa, Bartholomew of Smyrna, Archbishop Job of Telmessos and the Chief Secretary of the Holy Synod Archimandrite Joachim Billis. More at https://www.ecupatria.org/2018/04/12/president-of-ukraine-visited-the-ecumenical-

patriarchate/

20 'The United local Orthodox Church will not become a state church', The Official Website of the President of Ukraine (in Ukrainian), 17 April 2018, http://www.president.gov.ua/ru/news/yedina-pomisna-pravoslavna-cerkva-ne-stanederzhavnoyu-prezi-47010 
21 'Ukrainian Lawmakers Back President's Move To Obtain Autocephalous Status For Orthodox Church', 19 April2018, at https://www.rferl.org/a/ukraine-lawmakers-backpresident-move-to-obtain-autocephalous-status-for-orthodox-church/29176970.html

${ }^{22}$ It is worth noting that the Greek original of the Communique mentions 'communication' while the English translation says that Holy Synod is going to 'communicate and coordinate'. https://www.patriarchate.org/announcements/asset publisher/MF6geT6kmaDE/content/anakoinothen-tes-agias-kai-ieras-synodou-22-042018-? 101_INSTANCE MF6geT6kmaDE languageId=el_GR; https://www.patriarchate.org/announcements/lasset publisher/MF6geT6kmaDE/content/anakoinothen-tes-agias-kai-ieras-synodou-22-042018-? 101 INSTANCE MF6geT6kmaDE languageId=en US

23 'Report of His Holiness Patriarch Filaret at a conference in the European Parliament' (in Ukrainian), 3 May 2018, at https://www.cerkva.info/posts/dopovid-sviatiishoho-patriarkhafilareta-na-konferentsii-u-yevropeiskomu-parlamenti

${ }^{24}$ Erasmus, 'Between Greece and Russia, Faith and Diplomacy Connect in Curious Ways', The Economist, 29 May 2016 at https://www.economist.com/erasmus/2016/05/29/between-greeceand-russia-faith-and-diplomacy-connect-in-curious-ways

25 'The Ukrainian President in visit to Romanian Patriarchate' (in Romanian), 21 April 2016, at http://patriarhia.ro/presedintele-ucrainei-in-vizita-la-patriarhia-romana-8770.html

${ }^{26}$ Back in 2010, Novinsky managed to isolate heavily ill Head of the UOC-MP Volodymyr and tried to promote a young bishop Antony to the position of power. Antoniy later became Chancellor of the UOC-MP and promoted his people to the key positions in international affairs. See https://www.youtube.com/watch?v=Dwy9LAUPb-8

http://spzh.news/ru/zashhita-very/31328-ne-vsepravoslavnyy-sobor-promezhutochnie-itogi http://spzh.news/ru/news/30820-ekspert-konstantinopolskiy-patriarkhat-ne-sumel-primiritnesoglasnykh-v-preddverii-vsepravoslavnogo-; https://www.youtube.com/watch?v=YPAYyuExf9A

${ }^{27}$ The model of the letter is published at https://www.ukrinform.ua/rubric-society/2450726svasenikam-upc-mp-masovo-proponuut-pisati-skargi-patriarhu-varfolomiu.html

28 'Mass distribution of the letter-complaints to Bartholomew' (in Russian), Religiyna Pravda, 21 Mat 2018, at http://religionpravda.com.ua/2018/05/21/

29 'Press Service of the Zaporizhzhya Diocese of the UOC' (in Russian), 13 September 2018, at https://hramzp.ua/newsitem/avtokefaliya-vladyka-luka-otvetil-na-v

30 'In Transcarpathia, they stood up against the UOC (MP) and turned out to Poroshenk', (in Russian), 8 May 2018, http://anons-zak.com.ua/politika/25176-na-zakarpatt-povstali-protvupc-mp-ta-zvernulisya-do-poroshenka.html

31 'Tomos providing the autocephaly of the Ukrainian Orthodox Church has already been written' (in Ukrainian), $5^{\text {th }}$ TV Channel, at https://www.5.ua/polityka/tomos-pro-nadanniaavtokefalii-ukrainskii-pravoslavnii-tserkvi-vzhe-napysanyi-170693.html

32 Lana Samokhvalova, 'The end of Odessa 'tour' or the story of a press-tour pilgrimage', Ukrinform News Agency, (in Russian), 7 May 2018, at: https://www.ukrinform.ru/rubricpolytics/2455299-okoncanie-tureckoodesskoj-gastroli-ili-istoria-odnogo-pressturapalomnicestva.html

33 'Deputy Head of Presidential Administration Pavlenko pointed to some mis-representation of statements of the Polish Orthodox Church', (in Ukrainian), 19 May 2018, https://ua.censor.net.ua/news/3066985/zastupnyk glavy ap pavlenko vkazav na netochnist tsytuvannya pozytsiyi polskoyi tserkvy z boku upts 
34 'The delegation of the Ukrainian Orthodox Church - Moscow Patriarchate visits the Ecumenical Patriarchate' (in Greek), 23 June 2018, at https://fanarion.blogspot.com/2018/06/blog-post 23.html?m=1

35 'The Ecumenical Patriarch: Mother Church wishes unity in Ukraine' (In Greek), 1 July 2018, at https://fanarion.blogspot.com/2018/07/blog-post_1.html? m=1

36 'Member of the Holy Synod of the Ecumenical Patriarchate: The Moscow Church is not mother, but a daughter of the Ukrainian Church' (in Ukrainian), 7 November 2011, https://www.ukrinform.ua/rubric-society/2496544-clen-sinodu-vselenskoi-patriarhiimoskovska-cerkva-e-ne-matiru-a-dockou-ukrainskoi.html

37 The statement is available at http://news.church.ua/2018/06/26/zayavlenie-arxiereevukrainskoj-pravoslavnoj-cerkvi-prinyavshix-uchastie-v-arxierejskoj-soveshhanii-25-iyunyav-kievo-pecherskoj-lavre/?lang=ru . $\quad$ For more see https://lb.ua/society/2018/07/02/401786 avtokefaliya obratniy otschet .html

38 'Clergy and parishioners of Moscow Patriarchate wrote a letter to Bartholomew on the antiUkrainian activities of their hierarchs and request the Tomos of autocephaly' (in Ukrainian), Religious Information Service of Ukraine, 26 June 2018, at

https://risu.org.ua/ua/index/all news/confessional/orthodox relations/71622/

39 'Announcement of the Chancellery Council of Bishops of the Polish Orthodox Church' (in Polish), 9 May 2018, at: http://www.orthodox.pl/komunikat-kancelarii-sw-soboru-biskupow7/); Dmytro Horevoi, 'The Battle for local churches: The example of Poland' (in Russian) at https://site.ua/dmytro.horyevoy/13359/.

40 'Chairman of the Committee of the Russian Duma Sergei Gavrilov took part in the sitting of the Holy Synod of the Orthodox Church of Greece' (in Russian), The Website of State Duma of the Federal Assembly of the Russian Federation, 8 June 2018, at http://komitet222.km.duma.gov.ru/Novosti/item/16330670/

${ }^{41}$ Anastasia Golubeva and Svyatoslav Khomenko, 'Battle of Thrones. How Moscow and Kiev are secretly negotiating autocephaly' (in Russian), BBC Russian, 26 July 2018, at https://www.bbc.com/russian/features-44955800

42 'The Anointment of the Bishop of Switzerland Maximos today at Phanar' (in Greek), Ecclesiastical Speeches, 22 July 2018, at https://fanarion.blogspot.com/2018/07/blogpost $77 . \mathrm{html}$ ? $\mathrm{m}=1$

${ }^{43}$ Dmytro Horevoi, 'The Ukrainian Autocephaly: Activities of Our Diplomacy' ( in Russian) Religious Information Service of Ukraine, 21 June 2018 at https://risu.org.ua/ru/index/expert thought/analytic/71557/

44 'The Communique of the Holy Council of the Serbian Orthodox Church' (in Serbian), 19 April 2018, at http://spc.rs/sr/saopshtenje_za javnost_svetog_arhijerejskog_sabora_srpske; D. Horevoi, 'Church Geopolitics: The position of the Church of Serbia' (in Russian), Religious Information Service of Ukraine, 11 May 2018 at: https://risu.org.ua/ru/index/expert thought/open theme/71118

45 'His Holiness Patriarch Kirill meets with the Primate of the Serbian Orthodox Church' (in Russian), The Official Website of the Moscow Patriarchate, 23 May 2018 at: http://www.patriarchia.ru/db/text/5208760.html

46 'Joint Statement of the Serbian and Antiochian Orthodox Patriarchates', 19 October 2018 at https://antiochpatriarchate.org/en/page/joint-statement-of-the-serbian-and-antiochianorthodox-patriarchates/2053/

${ }^{47}$ J. Lester Feder, 'Macedonia suspects a Greek-Russian billionaire paid for violent protests to prevent it from joining NATO', BuzzFeed News, 18 July 2018 at https://www.buzzfeednews.com/article/lesterfeder/macedonia-russia-nato 
48 'Greece stopped issuing visas to priests from Russia' (in Russian), Fakty Newspaper, 9 August 2018, http://fakty.ua/277570-greciya-perestala-vydavat-vizy-svyacshennikam-izrossii ; and Jeremy Norman, 'What is behind Vladimir Putin's curious interest in Mount Athos?' The Spectator, 10 September 2016, at https://www.spectator.co.uk/2016/09/what-isbehind-vladimir-putins-curious-interest-in-mount-athos

${ }^{49}$ While IOPS's relations with Russia's secret services in the $19^{\text {th }}$ century remain unclear, its leaderships maintained close links with conservative geopolitical thinkers and the Czar's advisors on religious affairs (Gerd 2018). See also, 'Putting National Interest First: Soberly and firmly', Press-Release, The Website of the Ministry of Foreign Affairs of Greece, 10 August 2018, at https://www.mfa.gr/en/current-affairs/statements-speeches/putting-national-interestfirst-soberly-and-firmly.html

50 The organisational structure is available (in Russian) at http://www.ippo.ru/about/article/organizacionnaya-struktura-ippo-200324

51 'Russian spies in construction ELLAKTOR?', Iefimerida, 19 July 2018 (in Greek) at http://www.iefimerida.gr/news/431882/rosoi-kataskopoi-stin-kataskeyastiki-ellaktor

52 'The multi-religious procession of the UOC-MP in Kiev passed without a special adventure', Deutsche Welle, (in Ukrainian) 27 July 2018 at https://www.dw.com/uk/багатотисячнахресна-хода-упц-мп-в-києві-минула-без-особливих-пригод/а-44856758 ; and 'Religious procession of the UOC-KP on the occasion of the 1030th anniversary of the baptism of RusUkraine in Kiev', Unian Information Agency, (in Ukrainian) 28 July 2018, at https://www.unian.ua/multimedia/photo/10003101-krestnyy-hod-upc-kp-po-sluchayu-1030letiya-kreshcheniya-rusi-ukrainy-v-kieve.html

${ }^{53}$ Archbishop Daniel Participates in Synaxis of Hierarchs of The Ecumenical Patriarchate of Constantinople; Press Release of the Ukrainian Orthodox Church in the US, 1 September 2018; available at https://www.uocofusa.org/news 180901 1.html

54 The statement for the Holy Synod of the Russian Orthodox Church, 8 September 2018, at https://mospat.ru/en/2018/09/08/news163522/

${ }^{55}$ Statement of the Holy Synod of the Russian Orthodox Church concerning the uncanonical intervention of the Patriarchate of Constantinople in the canonical territory of the Russian Orthodox Church, Min. No. 69, 14 September 2018, at https://mospat.ru/en/2018/09/14/news163803/

56 Announcement, The Ecumenical Patriarchate's Website, 11 October 2018, at https://www.patriarchate.org/-/communiq-1

57 'Moscow-Affiliated Churches In Ex-Soviet Republics Fall In Line Over Ukraine Rift', Radio Free Europe / Radio Liberty, 18 October 2018, at https://www.rferl.org/a/moscow-affiliatedchurches-in-ex-soviet-republics-fall-in-line-over-ukraine-rift/29550875.html

${ }^{58}$ Holy Synod of Russian Orthodox Church appoints new bishops to administer parishes in Europe, U.S, 16 October 2018, at http://www.interfax-religion.com/?act=news\&div=14593

59 'Patriarch Bartholomew will meet in Istanbul with children of Ukrainian law enforcement officers who died in the Donbas', 18 October 2018, at http://religionpravda.com.ua/2018/10/18/

${ }^{60}$ Nicolai N. Petro, 'The Gospel According to Poroshenko: Politics, Religion, and the New Church of Ukraine', 4 April 2019, at http://yalejournal.org/article post/the-gospel-accordingto-poroshenko-politics-religion-and-the-new-church-of-ukraine/\# edn7

${ }^{61}$ Appeal of Archbishop of Simferopol and Crimean Clement, Kyiv Patriarchate Press-Release, 17 May 2019 at: https://www.cerkva.info/posts/zvernennia-arkhiiepyskopa-simferopolskohoi-krymskoho-klymenta

62 'Zelensky apologized for what he called tomos "thermosom" - Patriarch Filaret' (in Russian), UNIAN Information Agency, 29 April 2019, at https://www.unian.ua/politics/10533015zelenskiy-vibachivsya-za-te-shcho-nazvav-tomos-termosom-patriarh-filaret.html 
${ }^{63}$ Announcement, The Ecumenical Patriarchate's Website, 11 October 2018, at https://www.patriarchate.org/-/communiq-1

${ }^{64} \mathrm{We}$ have included the generic term 'official' to maintain anonymity of all interviewees. 